\title{
TOLERANSI DALAM ISLAM
}

\section{Jamil}

STIT Al-Amin Kreo Tangerang

jamil80@gmail.com

\begin{abstract}
:
Tolerance is an attitude that needed by people how to live in peace and love in the society which is different in culture, religion, social economy and soon. There is no word tolerance founded in the alQur'an, but explicitly, al-Qur'an explained the idea of tolerance that related to the Islamic teaching and the norm that used by muslim people to live side by side in the society which is different in religion, culture, and social economy.
\end{abstract}

Keywords: Tolerance, Indonesia, Traditions. 


$$
\begin{aligned}
& \text { ملخص: } \\
& \text { التسامح هو موقف يحتاج إليه الناس في حياتم تحت ظل } \\
& \text { الأمن والمحبة في تعدد الثقافات والأديان والاقتصاديات } \\
& \text { والاجتماعيات. لا يوجد قي القرآن لفظ "تسامح" لكن ولن وليك } \\
& \text { هناك أساس فكرة التسامح يوضحه القرآن بصراحة }
\end{aligned}
$$

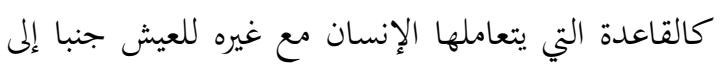

$$
\begin{aligned}
& \text { جنب في مجتمعه. } \\
& \text { كلمات مفتاحية : تسامح، إندونيسيا، تقاليد. }
\end{aligned}
$$

\section{A. Pengertian Toleransi}

Kata toleran berasal dan bahasa Inggris, kata sifat; artinya sabar; tolerance, kata benda; artinya kesabaran atau kelapangan dada. ${ }^{1}$ Dalam Kamus Besar Bahasa Indonesia (KBBI), kata 'toleran' bersifat menenggang (menghargai, membiarkan, membolehkan), pendirian (pendapat, pandangan, kepercayaan, kebiasaan, kelakuan dan sebagainya) yang berbeda atau bertentangan dengan pendirian sendiri. Toleransi artinya; 1) sifat atau sikap toleran, 2) batas ukur untuk penambahan atau pengurangan yang masih dibolehkan, 3) penyimpangan yang masih dapat diterima dalam pengukuran kerja. ${ }^{2}$

Toleransi dalam pengertian istilah umum adalah suatu sikap akhlak terpuji dalam pergaulan dimana antar sesama manusia saling menghargai dalam batas-batas yang digariskan oleh Islam. ${ }^{3}$

Memang tidak ada penyebutan kata 'toleransi' dalam al-Qur'an, namun secara eksplisit al-Qur'an menjelaskan konsep toleransi dengan batasan-batasan yang sangat jelas

1 Echols dan Shadili, Kamus Inggris-Indonesia, (Jakarta: Gramedia Pustaka Utama, 1996), h. 595.

2 Departemen Pendidikan dan Kebudayaan, Kamus Besar Bahasa Indonesia, (Jakarta: Balai Pustaka, 1995), cet. IV, h. 10651066.

3 Pemerintah DKI Jakarta, Proyek Peningkatan LBIQ DKI, (Jakarta: 1993/1994), h. 49. 
dan gamblang. Oleh karena itu, penjelasan ayat-ayat tentang toleransi dapat dijadikan pedoman dalam membina sebuah kerukunan hidup (toleransi) antar umat. ${ }^{4}$

Hal ini dapat dilihat sebagaimana dinyatakan dalam alQur`an:

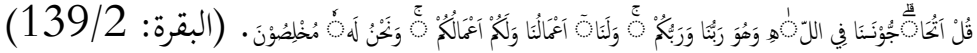

"Katakanlah: 'Apakah kamu memperdebatkan dengan kami tentang Allah, padahal Dia adalah Tuhan kami dan Tuhan kamu; bagi kami amalan kami, dan bagi kamu amalan kamu dan hanya kepada-Nya kami mengikhlaskan hati'," (QS. al-Baqarah [2]: 139).

Menurut Maraghi bahwa ayat di atas merupakan bantahan terhadap klaim-klaim Yahudi dan Nasrani yang menisbatkan dirinya kepada Ibrahim as, dengan mengatakan 'Tidak akan masuk surga kecuali orang yang beragama Yahudi atau Nasrani," (QS. al-Baqarah [2]: 111), "Hendaklah kamu menjadi penganut agama Yahudi atau Nasrani, niscaya kamu mendapat petunjuk," (QS. al-Baqarah [2]: 135). Kemudian nabi - melalui wahyunya - membantah pengakuan mereka itu. Sebab sebutan 'Yahudi' terjadi setelah Musa, dan sebutan 'Nasrani' baru terjadi setelah Isa. "Bagaimana Ibrahim disebut orang Yahudi atau Nasrani?". Lalu, nabi mengatakan "Amal kami untuk kami, dan amal kalian untuk kalian". Hal ini mengisyaratkan penghargaan Islam terhadap orang Yahudi dan Nasrani dalam memilih keyakinan, dan melakukan kegiatannya guna membangun kemaslahatan masyarakat, baik dalam persoalan agama atau dunia". ${ }^{5}$

Menurut Hikmat ibn Basyir ibn Yasin 'Toleransi atau tasāmuh adalah kehalusan, kelembutan dan kemudahan'. Ini bagian dari perbuatan ihsān terhadap jiwa yang melahirkan rasa cinta terhadap orang yang berbuat baik. Oleh karena itu, toleransi dapat menciptakan cinta kasih dan menghilangkan rasa benci terhadap orang IAIN". ${ }^{6}$

Dari pengertian di atas dapat dipahami bahwa toleransi adalah sikap tenggang rasa terhadap perbedaan orang IAIN

4 www.gatra.com, Abdul Fatah, Toleransi Beragama dalam Perspektif al-Qur'an.

5 Al-Maraghi, Tafsīr al-Marāghi, (Beirut: Dar al-Fikr, 1995), jilid. 1, vol. 1, h. 229.

6 Ibn Yasin, Samāhāt al-Islām fì al-Ta'āmul ma'a Ghairi alMuslimīn, (Maktabah Syamilah), h. 1.

242| Al Amin:Jurnal Kajian Ilmu dan Budaya Islam, Volume 1, No 2, 2018 
dalam berbagai hal dengan menghargai dan menghormati prinsip-prinsip hidup dalam batas-batas yang telah ditentukan oleh agama.

\section{B. Sejarah Singkat Toleransi di Indonesia}

Islam masuk ke Nusantara sekitar pada abad ke-7 M. melalui Selat Malaka, disyiarkan oleh para pedagang Arab, Gujarat, dan Persia. Masyarakat pribumi yang waktu itu memeluk agama Hindu dan Budha menerima kehadiran Islam dengan baik. Karena dakwah Islam yang disampaikan oleh para dai muslim dilakukan dengan pendekatan kultural yang ada di setiap daerah dan tidak mengusik tradisi keagamaan yang ada. ${ }^{7} \mathrm{Hal} \mathrm{mi}$ telah mengantarkan pada berdirinya kerajaan-kerajaan Islam di Nusantara yang dipelopori oleh para wali (Wali Songo) pada abad ke 15, khususnya di Pulau Jawa. Wali Songo adalah para mubalig yang dalam pengembangan Islamisasinya menyesuaikan dengan sosio-kultural masyarakat yang ada. Seperti kenduri, selamatan, sesaji dan sebagainya. Hal ini mengingat kebiasaan itu sulit untuk ditinggalkan oleh mereka. Para wali menyetujui untuk memberikan toleransi kepada masyarakat yang saat itu menganut ajaran Hindu dan Budha melakukan adat-istiadat yang sudah mengakar. Namun dalam penyampaian dakwahnya, adat-istiadat itu diberi warna Islam. ${ }^{8}$

Dalam misi dakwahnya, seperti Sunan Bonang meramu 'seni wayang' dan musik 'gamelan' dengan menyisipkan nilai-nilai Islam. Syair lagu yang diciptakannya berisi pesan tauhid, sikap menyembah kepada Allah Swt, dan tidak menyekutukannya. Setiap lagu diselingi dengan Syahādatain (dua kalimat syahadat) yang dikenal dengan 'Sekaten'. Permainan anak-anak dengan napas Islam, diciptakan oleh Sunan Giri, seperti Jelungan, Jarnuran, Gendi Ferit, Jor, Gula Ganti, Cublak-cublak Suweng, dan Ilir-ilir. Sunan Derajat seorang yang berorientasi pada kegotong-royongan dalam dakwahnya, menciptakan tembang Jawa, yaitu tembang Pangkur, yang sampai saat ini masih

7 Sofia Rangkuti-Hasibuan, Sosiologi Agama: Kajian Masyarakat Islam Di Indonesia, (Jakarta: Foundation for Human Resource and Technology Development/Fortech, t. t.h.), h. 53-62.

8 Depag RI, Ensiklopedi Islam, (Jakarta: t. p., 2001), jilid. 5, h. 173-176. 
banyak digemari oleh masyarakat. Sunan Kalijaga, mengembangkan seni 'wayang purwa' (wayang kulit) yang bercorak Islami, mengarang aneka cerita wayang yang bernapaskan Islam, terutama mengenai etika yang digunakan untuk menarik masyarakat masuk Islam. Ia juga bukan hanya dalam seni wayang, tetapi juga mengembangkan dalam seni suara, seni ukir, seni busana, seni pahat dan seni kesusasteraan. Seni ukir terlihat dan corak batik dengan motif burung yang oleh Sunan Kalijaga disebut 'Kukula'. Sunan Muria dalam penyiaran dakwah Islam lebih berorientasi pada pengadaan lembaga (pesantren) untuk mendidik para pedagang, nelayan dan rakyat biasa. Hasil ciptaan seninya adalah tembang dakwah Sinom dan Kinani. ${ }^{9}$

Islamisasi yang dilakukan oleh para wali terhadap masyarakat di pulau Jawa khususnya, menggambarkan sikap toleransi terhadap eksistensi tradisi yang sudah mengakar ratusan tahun pada masyarakat Jawa yang notabene penganut ajaran Hindu dan Budha.

\section{Dasar-Dasar Ajaran Toleransi}

Salah satu nikmat yang Allah anugerahkan kepada manusia adalah diutusnya Nabi Muhammad Saw dengan membawa sebuah agama rahmat bagi alam semesta. Rahmat ini tergambar dalam bentuk tasāmuh (toleransi), ampunan, dan saling memberi nasihat, yang tertuang dalam nașs-nașs al-Qur'an dan al-Sunnah. Rahmat ini pun terwujud pertama kali di Madinah dan sikap nabi dalam pergaulannya baik terhadap sesama muslim atau terhadap non-muslim yang meliputi semua aspek kehidupan. ${ }^{10}$ Konsep toleransi yang ditawarkan al-Qur'an sangatlah rasional, praktis dan mudah. Hidup rukun, damai, serta memahami segala macam perbedaan yang muncul dalam kehidupan manusia merupakan cita-cita al-Qur'an sebagai rahmat bagi alam semesta. Sebagaimana diungkapkan oleh Sayid Sabiq:

9 Departemen Pendidikan dan Kebudayaan, Kamus Besar Bahasa Indonesia, (Jakarta: Balai Pustaka, 1995), cet, IV, h. 174182.

10 Ibn Yasin, Samāhāàt al-Islām fĩ al-Ta'āmul ma'a Ghairi alMuslimin.

244| Al Amin:Jurnal Kajian Ilmu dan Budaya Islam, Volume 1, No 2, 2018 


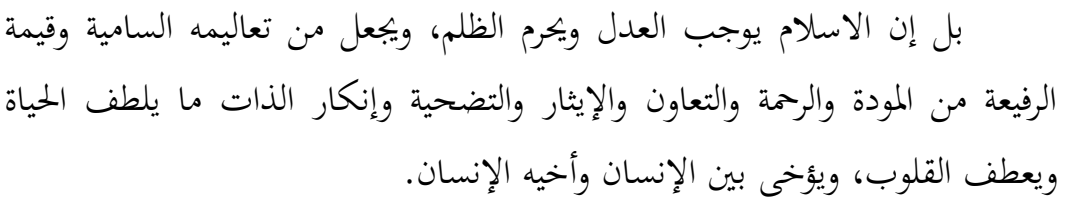

"Bahkan Islam mengharuskan (umatnya) berbuat adil dan mengharamkan kezaliman, dan menjadikan ajarannya mulia, dan bernilai tinggi tentang cinta, kasih sayang, kerja sama, patriotis, pengorbanan, tidak mementingkan pribadi dengan memperhalus budi pekerti dan perasaan hati, serta membangun persaudaraan antar manusia." 11

Sabiq menambahkan, 'Islam tidak hanya berbicara pada satu aspek dasar saja, tetapi Islam membentuk hubungan antar pribadi, kelompok, dan negara sebagai hubungan perdamaian dan keamanan. Baik hubungan antar muslim dengan muslim, atau antar hubungan muslim dengan non-muslim'. ${ }^{12}$

Hubungan antar sesama muslim adalah hubungan yang diikat oleh kesamaan akidah, bukan diikat oleh perbedaan nasab dan silsilah, warna kulit, bahasa, budaya, status sosial, pangkat dan kedudukan. Sebagaimana firman Allah:

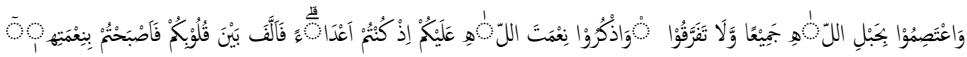

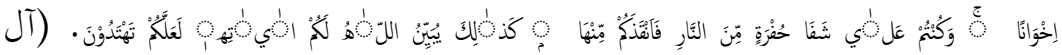
عمران:103/3)

"Dan berpeganglah kamu semuanya kepada tali (agama) Allah, dan janganlah kamu bercerai berai, dan ingatlah akan nikmat Allah kepadamu ketika kamu dahulu (masa Jahiliah) bermusuh-musuhan, maka Allah mempersatukan hatimu, lalu menjadilah kamu karena nikmat Allah, orang-orang yang bersaudara; dan kamu telah berada di tepi jurang neraka, lalu Allah menyelamatkan kamu dari padanya. Demikianlah Allah menerangkan ayat-ayat-Nya kepadamu, agar kamu mendapat petunjuk," (QS. Āli 'Imrān [3]: 103).

11 Sayyid Sabiq, Fiqh al-Sunnah, (Beirut: Dar al-Fikr, 1981), jilid. III, h. 7.

12 Sayyid Sabiq, Fiqh al-Sunnah, jilid. III, h. 7. 
Sementara dalam ayat lain:

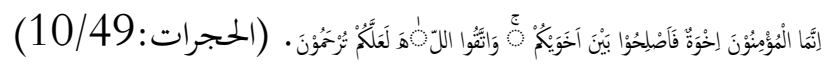

"Orang-orang beriman itu sesungguhnya bersaudara. Sebab itu damaikanlah (perbaikilah hubungan) antara kedua saudaramu itu dan takutlah terhadap Allah, supaya kamu mendapat rahmat," (QS. al-Hujurāt [49]: 10).

Sementara hubungan muslim dengan non-muslim adalah hubungan yang diikat oleh aspek sosial, seperti antara IAIN; rasa kekeluargaan, pertemanan, budaya atau politik, sebagaimana diungkapkan oleh Sabiq di atas. Namun demikian, aspek ibadah dan keyakinan mereka tetap dihargai oleh Islam. Sebagaimana firman Allah:

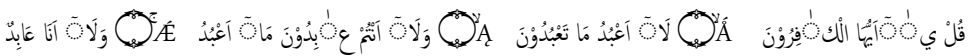

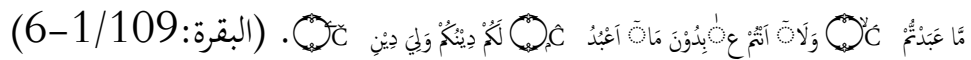

"Katakanlah: 'Hai orang-orang kafir, aku tidak akan menyembah apa yang kamu sembah, dan kamu bukan penyembah Tuhan yang aku sembah, dan aku tidak pernah menjadi penyembah apa yang kamu sembah, dan kamu tidak pernah (pula) menjadi penyembah Tuhan yang aku sembah, untukmu agamamu, dan untukkulah, agamaku'," (QS. alKāfirūn [109]: 1-6).

Pada ayat lain, Allah Swt berfirman:

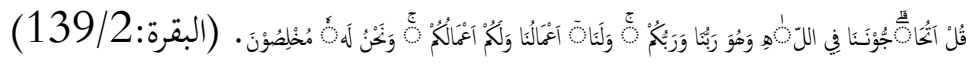

"Bagi kami amalan kami, dan bagi kamu amalan kamu dan hanya kepada-Nya kami mengikhlaskan hati," (QS. a1Baqarah [21]: 139).

Oleh karena itu, dalam hubungannya dengan keyakinan (akidah) dan ibadah, Islam melarang adanya iltibās dengan keyakinan dan ibadah di luar Islam. ${ }^{13}$ Sebab konsep keyakinan dalam Islam tidak sama dengan konsep keyakinan agama IAIN. Konsep keyakinan Islam merupakan doktrin monoteisme yang diberlakukan bagi setiap manusia, dan harus diterima dengan sadar, lihat QS. Āli 'Imrān [3]:

13 Lihat Himpunan Fatwa MUI, h. 109-114.

246| Al Amin:Jurnal Kajian Ilmu dan Budaya Islam, Volume 1, No 2, 2018 
19.14 Demikian pula ibadah dalam Islam bukan hanya sekadar zikir (puji-pujian) ruhani saja, juga bukan pula apa yang hanya terlintas dalam sanubari, tetapi ibadah dalam Islam merupakan gerak fisik yang disertai dengan gerak jiwa dan dalam. Semuanya berjalan secara integral, bahkan menyatu dengan akidah itu sendiri. ${ }^{15}$ Oleh karena itu persoalan akidah dan ibadah dalam perspektif Islam merupakan prinsip dasar yang dapat menentukan amal dan perbuatan manusia. Sebagaimana diungkapkan oleh Imam Nawawi yang dikutip oleh al-Malibari dalam kitab Irsyād al'Ibād:

$$
\begin{aligned}
& \text { ونقل النووي في شرح مسلم اتفاق أهل السنة من المحدثين والفقهاء والمتكلمين } \\
& \text { على أن من آمن بقلبه، ولم ينطق بلسانه مع قدرته كان مخلدا في النار انتهى. }
\end{aligned}
$$

"Imam Nawawi menukil dalam Syarah Muslim tentang kesepakatan pendapat Ahlussunnah dari kalangan ahli hadits, fuqahā dan mutakallimin bahwa orang yang beriman dalam hatinya, tetapi tidak mengucapkan (syahadat) padahal ia mampu (mengucapkannya), maka kekal di neraka,"16

Demikian pula menurut al-Qur`an bahwa seseorang yang tidak beriman segala perbuatan baiknya tidak diterima.

Firman Allah:

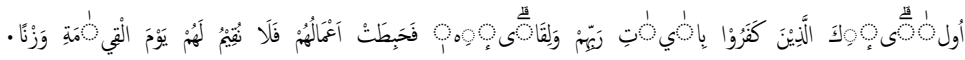

$$
\begin{aligned}
& \text { (الكهف:105/18) }
\end{aligned}
$$

"Mereka itu orang-orang yang telah kufur terhadap ayatayat Tuhan mereka dan (kufur terhadap) perjumpaan dengan Dia, maka hapuslah amalan-amalan mereka, dan kami tidak mengadakan suatu penilaian bagi (amalan) mereka pada hari Kiamat," (QS. al-Kahfi [18]: 105).

Menurut penulis, secara umum toleransi dalam Islam harus melihat tiga aspek kerangka dasar ajaran Islam; (1) Aqidah, (2) Syariah, dan (3) Akhlak. Aqidah secara etimologis

14 Marcel A. Boisard, Humanisme Dalam Islam, terj. oleh M. Rasjidi, (Jakarta: Bulan Bintang, 1980), h. 187.

15 Muhammad Quthub, Integritas Individu dan Masyarakat, terj. oleh Kathur Suhardi, (Jakarta: Mantiq, 1991), h. 151.

16 Zainuddin al-Malibari, Irsyād al-'Ibād ilā Sabìl al-Rasyād, (t. p.: Dar al-Nasyr, t. th.), h. 1. 
adalah ikatan. Dalam pengertian teknis, aqidah adalah iman yang terinci atas; percaya kepada Allah, malaikat, kitabkitab, para Rasul, hari akhir, dan takdir Allah. Oleh karena itu, akidah selalu dikaitkan dengan rukun Iman. ${ }^{17}$

Kata 'syariah' secara etimologi adalah jalan yang ditempuh. ${ }^{18}$ Dalam pengertian teknis syariah adalah normanorma Ilahi yang mengatur hubungan manusia dengan Tuhan, dan manusia dengan alam lingkungannya. Kaidahkaidah yang mengatur manusia dengan Tuhan yang disebut ibadah mahdah (murni) membahas persoalan; kaidah-kaidah tahärah, (bersuci), dan kaidah-kaidah rukun Islam. Kaidah yang mengatur hubungan manusia dengan Tuhan ini tidak boleh ditambah atau dikurangi. Oleh karena hubungan manusia dengan Tuhan sifatnya tetap, tidak berubah. ${ }^{19}$ SeIAIN kaidah-kaidah ibadah, syariah juga mengatur kaidahkaidah muamalah yang dasar-dasarnya ditentukan oleh alQuran dan al-Hadits, dan sifatnya terbuka bagi manusia untuk berijtihad. Karena sifatnya terbuka, dalam muamalah "berlaku asas umum" yaitu pada prinsipnya semua perbuatan boleh dilakukan, kecuali ada kaidah yang melarangnya dalam al-Qur'an atau al-Hadits, seperti larangan membunuh, merampok, berzina dan sebagainya. Oleh karena itu, kaidah-kaidah dalam muamalah ini dapat berubah sesuai dengan kondisi zaman. Bahkan dalam bidang muamalah ini boleh dimodernisasi, sepanjang tidak bertentangan dengan pokok-pokok ajaran Islam secara umum. ${ }^{20}$

Selain akidah dan syariah terdapat pula akhlak. Kata 'akhlak', secara etimologi adalah tingkah laku, perangai, sikap, atau watak. ${ }^{21}$ Akhlak secara terminologi, menurut Imam Ghazali, dalam kitabnya Ihyà' 'Ulümiddìn, jilid III, hal. 52, mengatakan:

17 Muhammad Daud Ali, Asas-asas Hukum Islam, (Jakarta: Rajawali, 1991), h. 29-30.

18 Ibn Katsir, Tafsīr Ibn Katsīr, (Beirut: Dar al-Fikr, t.th.), Juz 3, h. 129.

19 Muhammad Daud Ali, Asas-asas Hukum Islam, h. 31.

20 Muhammad Daud Ali, Asas-asas Hukum Islam, h. 33.

21 A. W. Munawir, Kamus Al-Munawir: Arab-Indonesia Terlengkap, (Surabaya: Pustaka Progressif, 1997), h. 364.

248| Al Amin:Jurnal Kajian Ilmu dan Budaya Islam, Volume 1, No 2, 2018 


$$
\begin{aligned}
& \text { فالحلق عبارة عن هيئة في النفس راسخة عنها تصدر الأفعال بسهولة ويسر من } \\
& \text { غير حاجة إلى فكر وروية، فإن كانت الهيئة بحيث تصدر عنها الأفعال الجميلة المحمودة } \\
& \text { عقلا وشرعا سميت تلك الهيئة خلقا حسنا، وإن كان الصادر عنها الأفعال القبيحة } \\
& \text { سميت الهيئة التي هي المصدر خلقا سيئا. }
\end{aligned}
$$

"Akhlak adalah perangai jiwa yang melekat dalam jiwa yang melahirkan perbuatan-perbuatan dengan mudah, tanpa mempertimbangkan pikiran (lebih dahulu. Apabila perangai itu melahirkan perbuatan yang baik dan terpuji menurut akal dan agama, perangai itu disebut akhlak yang baik. Dan apabila yang lahir itu perbuatan-perbuatan yang buruk, maka perangai itu disebut akhlak yang buruk."22

Pada prinsipnya, akhlak merupakan sikap dan perbuatan seseorang yang menggambarkan kepribadian dalam hubungannya dengan pihak IAIN; baik hubungannya dengan Tuhan, atau dengan manusia dan alam di sekitarnya. Sikap dan perbuatan seseorang menjadi ukuran eksistensi kepribadiannya dengan melihat akhlaknya. Akhlak mulia ini memiliki peranan penting dalam membangun masyarakat yang harmonis. ${ }^{23}$

Gambaran di atas merupakan sistem yang mengatur kehidupan manusia yang berkaitan dengan hak dan kewajibannya terhadap Tuhan dan terhadap sesama. Hak dan kewajiban manusia telah dideklarasikan oleh Nabi Muhammad Saw pada saat haji Wadā' dan didengar oleh ribuan manusia, sebagai cita-cita Islam untuk mengembalikan manusia pada fitrahnya. ${ }^{24}$ Salah satu isi khutbah yang dikumandangkan saat itu, sebagai berikut:

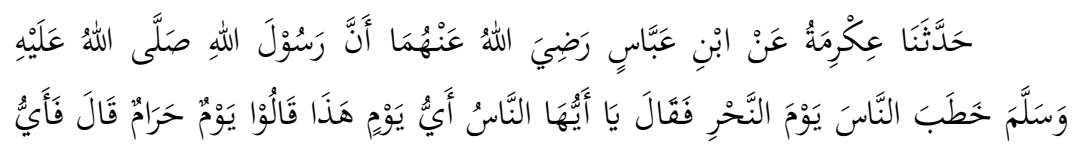

22 Al-Gazali, lhya Ulumuddin, (Semarang; Toha Putra, 1985), jilid III, h. 52 .

23 Zahruddin dan Hasanudin, Pengantar Studi Akhlak, (Jakarta: Rajagrafindo Persada, 2004), h. 14.

24 Muhammad Husain Haikal, Sejarah Hidup Muhammad, terj. oleh Ali Audah, (Jakarta: Litera Antar Nusa, 1989), cet. XX, h. 547-548. 


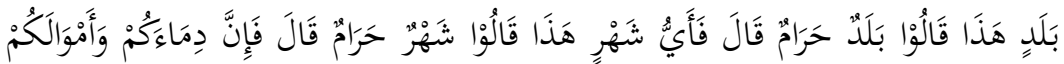

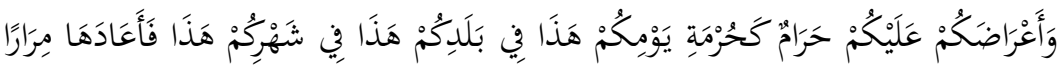

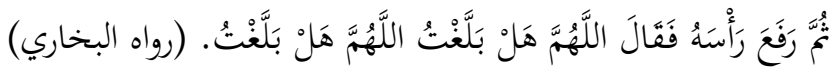

"Diceritakan oleh Ikrimah dan Ibnu Abbas bahwa Rasulullah Saw berkhutbah (di hadapan) manusia pada hari Nahr, beliau bersabda; 'Wahai manusia, hari apa ini?'. Mereka menjawab, 'ini hari yang mulia'. Beliau bersabda, 'Negeri apa ini?'. Mereka menjawab, 'Negeri yang mulia'. Beliau bersabda, 'Bulan apa ini?'. Mereka menjawab, 'Bulan mulia'. Beliau bersabda, 'Sesungguhnya darah, harta, dan kehormatan kalian diharamkan atas kalian, seperti (diharamkannya) pada hari ini pada bulan ini, dan di negeri ini. Beliau mengulang-ulang khutbahnya, lalu mengangkat kepalanya, seraya bersabda: 'Ya Allah, bukankah aku telah sampaikan?, Ya Allah, bukankah aku telah sampaikan?'," (HR. Bukhari).

Ada tiga kata kunci dalam teks di atas; pertama kata dimā'akum (darah) berkaitan dengan jiwa, agama dan kepercayaan, serta kebebasan berpendapat. Kedua, kata amwālakum (harta) berkaitan dengan kekayaan, bekerja, kekuasaan, kedudukan dan jabatan yang mengarah pada bentuk usaha yang dapat menghasilkan harta. Dan ketiga kata a'rādakum (kehormatan) yang berkaitan dengan pribadi, keluarga, keturunan, masyarakat dan bangsa. Semua itu dinyatakan dengan kata harāmun sebagai bentuk kemuliaan yang harus dihormati.

Jauh sebelum United Nations Educational, Scientific, and Cultural Organization (UNESCO), merumuskan deklarasi hak asasi manusia pada tahun 1981, empat belas abad yang lalu Nabi telah menyampaikan deklarasi tersebut kepada umat pada saat haji Wadā'. Tujuannya adalah untuk memberikan kehormatan dan harga diri kepada manusia, menghapuskan eksploitasi, oppression (penindasan), dan ketidakadilan. Hak asasi manusia yang diberikan Islam bersumber dari Tuhan. Karena hanya Tuhan semata pembuat dan pemilik hukum yang mutlak. Maka tidak ada pemimpin, pemerintahan, majelis atau otoritas IAIN yang dapat membatasi, menghapus atau melanggar terhadap hak asasi yang diberikan Tuhan kepada manusia. 
Gambaran di atas, menurut penulis bahwa dasar-dasar toleransi dapat dirumuskan sebagai berikut:

1. Prinsip bahwa perbedaan keyakinan manusia merupakan sunnatullah yang langgeng. (QS. al-Māidah [5]: 48).

2. Prinsip bahwa keyakinan yang salah diserahkan sepenuhnya kepada Allah, karena Dia Yang Maha Tahu dan memiliki hak istimewa untuk mengadili hamba-Nya. (QS. al-Nahl [16]: 125).

3. Prinsip bahwa dalam teologi semua umat manusia memiliki agama alamiah (fitrah) yang melekat dengan fitrah spiritual dan moral yang diasumsikan sebagai kebenaran dan kebaikan.

Dengan tiga prinsip inilah Islam menjamin kebebasan berkeyakinan dan berpendapat, menciptakan keamanan dan kedamaian hidup setiap orang, menempatkan manusia dalam persamaan hak dan kewajibannya, serta membangun persaudaraan antar sesama muslim dan antara umat yang berbeda agama.

\section{Pengembangan Sikap Toleransi}

Kehidupan manusia selalu dinamis dan terus mengalami perkembangan dalam semua sektor. Berbagai persoalan pun muncul sejalan dengan perkembangan waktu dan tempat manusia itu hidup. Demikian halnya dengan keberagamaan masyarakat dan interpretasinya terhadap ajaran agama yang dianut.

Indonesia dikenal sebagai masyarakat multi agama dan budaya. Jumlah pemeluk agama menunjukkan angka kuantitatif yang sangat mengesankan. Demikian pula tempat peribadatan jumlahnya meningkat tajam menjadi lebih dari 660 ribu buah. Jumlah jamaah haji dari tahun ke tahun juga meningkat. Fakta ini membuktikan agama se-IAIN telah menjadi bagian dari sejarah, juga telah membudaya dan melembaga.

Meskipun Indonesia bukan negara agama, tetapi realitas masyarakat yang agamis menjadikan negara berkepentingan terhadap terciptanya tata kehidupan beragama yang berkualitas, harmonis dan toleran. Meskipun demikian, sebelum tahun 2000.

Agama sering diletakkan dalam posisi yang tidak proporsional. Agama dieksploitasi dan dijadikan alat legitimasi politik dan kekuasaan. Intervensi negara terhadap 
agama telah memunculkan ketegangan-ketegangan mubazir antara negara dan masyarakat agama di satu sisi, dan antara masyarakat agama yang satu dan masyarakat agama yang IAIN. Eksploitasi dan intervensi tersebut juga berakibat pada lahirnya ekspresi keagamaan yang timpang dan kecaman yang sifatnya merusak (destruktif). ${ }^{25}$

Kemajemukan agama perlu mendapatkan perhatian serius, karena sangat potensial memicu konflik dan memunculkan disintegrasi, sebagaimana peristiwa Ambon pada tahun 1999, dan Ahmadiyah di Parung, Bogor, Sabtu 9 Juli 2005. ${ }^{26}$ Program pluralisme dalam bentuk kerukunan antar umat tampaknya masih sebatas wacana intelektual dan politis. Pentingnya dialog dan hubungan harmonis umat beragama belum mampu menyentuh kesadaran kolektif masyarakat dan masih sebatas wacana formal. Indikatornya masih rentannya masyarakat agama terhadap isu-isu agama dan SARA serta masih maraknya konflik agama.

Partisipasi kaum agamawan dalam menyelesaikan konflik sosial juga belum berada dalam level aliansi aksi dan konseptual strategis. Sementara ini kaum agamawan lebih sering berpidato dari pada action (tindakan), apalagi terlibat dalam penelitian mengenai pluralisme dan kedamaian sosial. Karena itu lebih menampakkan fitnah dari pada memberi solusi konkrit dan jauh dan pendekatan sosiologis empatik.

Sebenarnya agama telah memberikan sumbangan bagi kehidupan umat sebagai landasan etis bagi penciptaan manusia yang berbudi luhur. Namun ajarannya sering dimarginalkan dan kepedulian sosial dan lingkungan. Solidaritas sosial dan dialog lintas agama belum mewarnai budaya masyarakat. Dengan demikian dialog tentang pluralisme selalu diperlukan dan belum kedaluwarsa.

Di sisi IAIN dalam pengembangan toleransi, para tokoh agama lebih mementingkan seremonial di atas substansi dan fungsi agama itu sendiri, sehingga hanya melahirkan kesalehan individu di atas kesalehan sosial dan hanya memiskinkan rasa kesadaran umat untuk hidup berdampingan. Hal ini masih tampak jelas, fenomena lemahnya pemahaman dan penghayatan umat terhadap agama, menguatnya tribalisme (kesukuan), dan maraknya

25 Abdurrahman Mas'ud, "Suara Merdeka”, Kamis, 29 Mei 2003.

26 www.nahimunkar.com.

252| Al Amin:Jurnal Kajian Ilmu dan Budaya Islam, Volume 1, No 2, 2018 
budaya kekerasan sehingga nyawa menjadi tidak bernilai. Padahal tradisi menghormati orang IAIN serta respek (menghormati) beda pendapat sesungguhnya merupakan tiang utama demokrasi untuk membangun hidup bertoleransi dalam budaya masyarakat Indonesia. Barangkali hal ini tidak bisa dipisahkan dari suburnya ajaran taqlid (irrational appeal), fanatisme dalam budaya kita, serta kolonialisme dan imperalisme.

Melihat kenyataan ini harus ada upaya memutar arus untuk mengembangkan tradisi menghormati dan mencari hikmah beda pendapat yang dilandasi dengan nilai budaya dan moral agama. Menarik untuk disimak dalam al-Qur`an tidak kurang dari 173 kali kata sami'a (mendengarkan secara aktif) disebutkan dengan berbagai macam bentuk dan substansinya yang mengarah pada penghargaan orang IAIN.

Dari gambaran fenomena di atas, penulis ingin menawarkan beberapa poin. Pertama, perlunya peningkatan kualitas keimanan dan ketakwaan aktif kepada Tuhan Yang Maha Esa dengan memperdalam pemahaman dan kesadaran beragama, sehingga melahirkan nilai-nilai aktif dan dinamis. Kedua, berkaitan dengan upaya pengembangan sikap toleransi beragama di Indonesia, peran institusi pendidikan formal, termasuk institusi pendidikan yang dimiliki dan dikelola oleh organisasi keislaman, sangat penting. Oleh karena itu, sumbangan mereka bagi pembentukan karakter anak didik yang intelek, religius dan sekaligus nasionalis perlu terus dikembangkan. ${ }^{27}$ Ketiga, perlunya dikembangkan budaya mengapresiasi dan mendengarkan orang atau kelompok IAIN secara empatik.

Pengembangan teologi sangat diperlukan dengan meningkatkan kualitas dialog sehat lintas agama melalui aksi bersama secara nyata, intensif, dan alami, bukan seremonial yang dipaksakan. Keempat, perlunya keteladanan dan kerja sama tokoh masyarakat, LSM, pemuka agama, ulama, cendekiawan, budayawan, dan pemerintah dalam menangani masalah-masalah sosial.

Secara fungsional, silaturahmii yang ditindaklanjuti dengan aksi sosial akan meringankan beban umat yang semakin kompleks.

Dengan demikian pengembangan sikap toleransi keberagamaan adalah satu keharusan. Dengan sikap

27 Bambang Widiatmoko, www.pendidikan.net. 
kemajemukan etnis, kerukunan antar umat seagama dan berbeda agama akan mampu berjalan langgeng, bukan kerukunan semu seperti yang berjalan selama ini. Kerukunan yang dimaksudkan adalah keharmonisan yang tumbuh alami, dari lubuk hati setiap insan yang beriman dengan disertai sikap saling pengertian secara aktif membangun kerukunan, kedamaian dan persaudaraan. 


\section{DAFTAR PUSTAKA}

A. W. Munawir, Kamus Al-Munawir: Arab-Indonesia Terlengkap, Surabaya: Pustaka Progressif, 1997.

Abdurrahman Mas'ud, "Suara Merdeka", Kamis, 29 Mei 2003.

Al-Gazali, lhya Ulumuddin, Semarang; Toha Putra, 1985, jilid III.

Al-Maraghi, Tafsìr al-Marāghi, Beirut: Dar al-Fikr, 1995, jilid. 1, vol. 1.

Bambang Widiatmoko, www.pendidikan.net.

Depag RI, Ensiklopedi Islam, Jakarta: t. p., 2001, jilid. 5

Departemen Pendidikan dan Kebudayaan, Kamus Besar Bahasa Indonesia, Jakarta: Balai Pustaka, 1995, cet. IV

Departemen Pendidikan dan Kebudayaan, Kamus Besar Bahasa Indonesia, Jakarta: Balai Pustaka, 1995, cet, IV.

Echols dan Shadili, Kamus Inggris-Indonesia, Jakarta: Gramedia Pustaka Utama, 1996.

Himpunan Fatwa MUI.

Ibn Katsir, Tafsìr Ibn Katsìr, Beirut: Dar al-Fikr, t.th., juz 3.

Ibn Yasin, Samāhāt al-Islām fĩ al-Ta'āmul ma'a Ghairi alMuslimin, Maktabah Syamilah.

Marcel A. Boisard, Humanisme Dalam Islam, terj. oleh M. Rasjidi, Jakarta: Bulan Bintang, 1980.

Muhammad Daud Ali, Asas-asas Hukum Islam, Jakarta: Rajawali, 1991.

Muhammad Husain Haikal, Sejarah Hidup Muhammad, terj. oleh Ali Audah, Jakarta: Litera Antar Nusa, 1989, cet. XX.

Muhammad Quthub, Integritas Individu dan Masyarakat, terj. oleh Kathur Suhardi, Jakarta: Mantiq, 1991.

Pemerintah DKI Jakarta, Proyek Peningkatan LBIQ DKI, Jakarta: 1993/1994. 
Sayyid Sabiq, Fiqh al-Sunnah, Beirut: Dar al-Fikr, 1981, jilid. III.

Sofia Rangkuti-Hasibuan, Sosiologi Agama: Kajian Masyarakat Islam Di Indonesia, Jakarta: Foundation for Human Resource and Development/Fortech, t. t.h. Technology

www.gatra.com, Abdul Fatah, Toleransi Beragama dalam Perspektif al-Qur'an.

www.nahimunkar.com.

Zahruddin dan Hasanudin, Pengantar Studi Akhlak, Jakarta: Rajagrafindo Persada, 2004.

Zainuddin al-Malibari, Irsyād al-'Tbād ilā Sabîl al-Rasyād, t. p.: Dar al-Nasyr, t. th. 